Мосов С. П., д-р військ. наук, професор ${ }^{1}$

Сєлюков О. В., д-р техн. наук, ст. наук. співроб. ${ }^{2}$ (0000-0001-7979-3434)

1 - Національний центр управління та випробувань космічних засобів, Київ;

2 - Київський національний університет будівництва і архітектури, Київ

\title{
Космічна розвідка в локальних війнах і збройних конфліктах сучасності
}

Резюме. На основі аналізу світового досвіду досліджено застосування розвідувальних супутників і супутників подвійного призначення в системі забезпечення бойових дій на прикладах відомих локальних війн і збройних конфліктів кінця XX-початку XXI століть: Ірак, 1991 рік; Югославія, 1999 рік; Афганістан, 2001 рік; Ірак, 2003 рік; Сирія, з 2014 року. Акцентовано увагу на особливостях застосування космічних апаратів розвідки, що були притаманні кожній із локальних війн з урахуванням відповідного театру воєнних дій, можливостей космічної розвідки держав, які брали в них участь. Наведено інформацію про орбітальні угруповання космічних апаратів, що виконували завдання розвідки в інтересах наземних військ у різних діапазонах довжин хвиль електромагнітного спектра. Зроблено висновки щодо тенденцій космічної розвідки, а також визначено перспективи розвитку космічного сегмента в системі забезпечення майбутніх бойових дій.

Ключові слова: космічна розвідка; збройна боротьба; локальна війна; театр воєнних дій; космічний апарат.

\section{Постановка}

Найхаракернииоюо рисою збройно̆ борогьи сучастес можна вважати ведення розвідки, передачу даних, управління військами та зброєю i вогневе ураження противника в масштабі реального часу [1].

Використання систем космічної розвідки (спостереження) або результатів космічної зйомки для вирішення завдань інформаційного забезпечення командування збройних сил у провідних країнах світу стало одним 3 найважливіших напрямів забезпечення національної безпеки цих країн.

Специфіка ведення космічної розвідки i тактико-технічні характеристики космічних засобів розвідки забезпечують досягнення таких цілей, як: отримання даних для виявлення ознак завчасної (безпосередньої) підготовки евентуального противника (агресора) до розв'язування війни; отримання даних про об'єкти суміжних держав і держав, що входять у систему геополітичних інтересів, для забезпечення своєчасного прийняття політичним та військовим керівництвом країни рішень щодо забезпечення ії безпеки і оборони.

Аналіз низки завдань, що виявилися необхідними для вирішення під час війни у південно-східному регіоні нашої країни, потрубує змістовного вивчення світового досвіду щодо застосування розвідувальних супутників i супутників подвійного призначення в локальних війнах і збройних конфліктах сучасності на різних ТВД, що, зі свого боку, допоможе конкретизувати завдання і визначити особливості та умови щодо їх застосування в інтересах інформаційного забезпечення підготовки та ведення бойових дій.

Аналіз останніх досліджень i публікацій. Питаннями, пов'язаними 3 різноманітними дослідженнями щодо застосування розвідувальних супутників для вирішення завдань забезпечення бойових дій під час підготовки та в ході локальних війн $\mathrm{i}$ збройних конфліктів займалася низка українських та іноземних фахівців і вчених: А. Андронов, Л. Артюшин, В. Волошин, Ю. Гунько, Л. Дода, В. Дорофеєв. Є. Кохен, А. Кузнєцов, Ю. Меньшаков, С. Мосов, Д. Пайсон, В. Присяжний, Д. П'ясковський, Ю. Ребрін, С. Станкевич, П. Фриз, В. Чуларис та ін.

Водночас, питання визначення завдань, особливостей і умов застосування космічних засобів розвідки і спостереження в інтересах виконання завдань інформаційного забезпечення військ на різних ТВД потребує проведення досліджень світового досвіду для подальшого використання отриманих результатів в Україні.

Мета статті - систематизувати на основі світового досвіду завдання, особливості та умови застосування іноземними країнами космічних засобів розвідки і спостереження у вирішенні завдань інформаційного забезпечення бойових дій військ у локальних війнах і збройних конфліктах сучасності на різних ТВД.

Виклад основного матеріалу. У сучасних війнах відмічається стійка тенденція 
перенесення все більших і більших зусиль розвідки в повітряно-космічний простір. Космічним засобам військового призначення відводиться не просто велика і важлива роль, вони розглядаються як системоутворюючі воєнно-технічні інструменти ведення збройної боротьби [2].

На сьогодні космічні засоби розвідки стали найважливішим джерелом інформації. Характерною рисою для війн останнього часу стало все активніше застосування комерційних космічних апаратів дистанційного зондування Землі подвійного призначення з розрізненною здатністю в кілька десятків сантиметрів.

Ще в 1995 році з'явилося висловлення стосовно значення космічного сегменту для держави: “Стало загальновизнаним, що у XX ст., а тим більше в наступні роки, космічна зйомка буде винятковим засобом, на якому базується прагнення нації до незалежності. Будучи позбавленої розвідувальних супутників, країна не тільки стає сліпою і глухою, але й визнає, що вона більше не входить у вищу лігу" [3]. Це гарне повчання для нашої української держави, яка на початку своєї незалежності входила до вищої ліги, а сьогодні знаходиться за її межами.

Проведений аналіз застосування космічних систем у локальних війнах $\mathrm{i}$ збройних конфліктах дає змогу стверджувати, що динаміка нарощування орбітального угруповання постійно зростала. У порівнянні з операцією “Буря пустелі” (1991) кількість космічних апаратів, що застосовувалися під

час бойових дій в Іраку в 2003 році збільшилася майже в три рази. До того ж $25 \%$ 3 них складали розвідувальні супутники, якими було здобуто майже $70 \%$ розвідувальної інформації про наземні об'єкти противника [1].

Війна в зоні Перської затоки (1991) стала першим i самим значним збройним конфліктом, де важливими у забезпеченні бойової діяльності багатонаціональних сил були космічні системи і засоби розвідки. Американські військові фахівці 3 подачі колишнього начальника головного штабу ВПС США генерала М. Макпіка визнали війну в зоні Перської затоки “першою війною космічної ери" тому, що в ній були задіяні військово-космічні засоби в інтересах підготовки і ведення бойових дій багатонаціональних сил [4].

Усього в період військового конфлікту в зоні Перської затоки було задіяне понад 60-ти супутників різного призначення шляхом дорозгортання супутників орбітального резерву і запуску нових. У район Перської затоки додатково була перенацілена частина супутників, що вирішували завдання в інтересах інших ТВД.

До складу орбітального угрупування розвідки, що забезпечувало дії багатонаціональних сил в операції "Буря в пустелі”, входило більше 20 космічних апаратів (далі - КА) видової й радіоелектронної розвідки, що мали високі технічні можливості (Табл. 1) [2, 4-8].

Таблиця 1

Космічні апарати розвідки і спостереження (БНС, Ірак, 1991)

\begin{tabular}{|c|c|c|c|}
\hline Країна & Найменування КА & Апаратура & Примітка \\
\hline США & КН-11 & ОЕР & військовий \\
\hline США & Lacrosse & РЛР & військовий \\
\hline США & Ferret & РТР & військовий \\
\hline США & Chalet & РТР & військовий \\
\hline США & White Cloud & РЕP & військовий \\
\hline США & Magnum & PР & військовий \\
\hline США & DSP & OЕР & військовий \\
\hline США & Landsat & OEC & цивільний \\
\hline Франція & Spot & OEC & цивільний \\
\hline
\end{tabular}

ОЕР - оптико-електронна розвідка; РЛР - радіолокаційна розвідка; РТР - радіотехнічна розвідка; PР - радіорозвідка; ОЕС - оптико-електронне спостереження; БНС - багатонаціональні сили

Під час операції "Буря в пустелі" космічні апарати видової розвідки забезпечували контроль району ведення бойових дій з періодичністю 4-6 разів на добу за сприятливих метеорологічних умов і 2-3 рази - за умови похмурої погоди. Їх застосування дало змогу розкрити основні ударні угруповання іракської армії та виділити першочергові об'єкти ураження. За допомогою космічних апаратів (КА) KH-11 i Lacrosse-1 велася розвідка других ешелонів армії Іраку, встановлювалися місця зосередження резервів, дислокації засобів доставки зброї масового знищення, авіації, ППО, уточнювалися координати пунктів військового і державного управління, важливих підприємств промисловості й об'єктів інфраструктури Іраку. Інформація застосовувалася також під час вибору маршрутів польоту і розрахунках 
польотних завдань для крилатих ракет Tomahawk.

Космічні апарати радіоелектронної розвідки давали змогу контролювати район Середнього Сходу. Вони використовувалися для викриття системи воєнного та державного управління Іраку і системи ППО, визначення типу, режиму роботи і місць розміщення РЛС, засобів зв'язку та радіоелектронної боротьби, виявлення діючих пунктів управління військами, перехоплення повідомлень в мережах військового зв'язку.

Виявлення пусків іракських оперативнотактичних ракет “Скад” здійснювалося завдяки KA DSP, оснащених апаратурою, що давала змогу визначати старт i азимут пусків балістичних ракет.

Загалом засоби космічної розвідки i спостереження давали змогу ефективно використовувати їхні дані під час планування масованих вогневих ударів із застосуванням високоточної зброї. Зокрема, на основі супутникової розвідувальної інформації можна було проводити оперативну оцінку ступеня ураження цілей для планування подальших ударів.

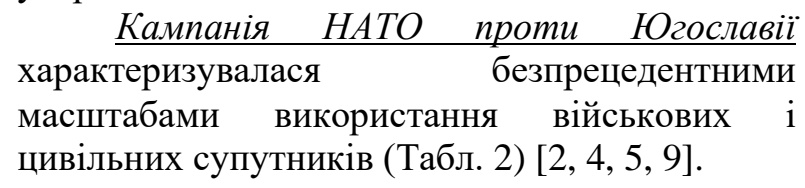
Таблиця 2

Космічні апарати розвідки і спостереження (НАТО, Югославія, 1999)

\begin{tabular}{|c|c|c|c|}
\hline Країна & Найменування КА & Aпаратура & Примітка \\
\hline США & KH-11 & OEP & військовий \\
\hline США & Lacrosse & РЛР & військовий \\
\hline США & Jumpseat & OEP & військовий \\
\hline США & Ferret & PTP & військовий \\
\hline США & Chalet & PTP & військовий \\
\hline США & Magnum & $\mathrm{PP}$ & військовий \\
\hline США & DSP & OEP & військовий \\
\hline США & Vortex & PTP & військовий \\
\hline США & Landsat & $\mathrm{OEC}$ & цивільний \\
\hline Франція & Spot & OEC & цивільний \\
\hline Франція & Helios & OEC & цивільний \\
\hline
\end{tabular}

Космічні засоби військового призначення мали не тільки важливого значення в операції “Союзницька сила” (1999), але й були системоутворюючими військово-технічними інструментами ведення бойових дій. США створили потужне угрупування космічних засобів різного призначення (понад 50 супутників). Над ТВД одночасно перебувало 812 космічних апаратів, які разом з повітряними та морськими носіями були основою бойових розвідувально-ударних систем. 3 космосу велося безперервне спостереження за ТВД супутниками оптико-електронної радіолокаційної розвідки.

За визнанням американців, в югославському конфлікті супутники повинні були вирішувати в основному тактичні завдання - відстежувати, куди направляються військові автоколони, і швидко передавати інформацію на бази ВПС. Однак з'ясувалося, що поки знімок із супутника потрапляв до кабіни бомбардувальника, проходило занадто багато часу. Унаслідок ефективність бомбових ударів по мобільних об'єктах - танкових колонах, скупченнях югославських військ була вкрай мала. Отже, вирішити завдання систематичного ураження живої сили і техніки 3 використанням космічної розвідки на ТВД коаліційним силам не вдалося. До цього, часто перешкодою ставала густа хмарність, що вкривала рухливі наземні об'єкти і не давала видової розвідки.

Космічні засоби розвідки надали активну підтримку антитерористичній операиіi в Афганістані (2001). Попереднє розвідувальне забезпечення операції проводилося $з$ використанням засобів видової розвідки, а також супутників для прослуховування мереж зв'язку.

Комплексна космічна розвідка території Афганістану проводилася 3 метою аналізу ефективності нанесення ракетно-бомбових ударів і виявлення нових цілей (Табл. 3) [2, 4, 5].

В антитерористичній операції досить активно використовувалися дані дистанційного зондування Землі 3 космосу 3 високою розрізненною здатністю. Влада США купила частину орбіти супутника KA Ikonos-2 для особистого користування. Знімки 3 КА Ikonos-2, а також 3 інших супутників NASA, використовувалися в Афганістані не тільки для розвідувальних операцій, а також для дослідження погодних умов i стеження за пиловими бурями, що ускладнювали дії пілотів літаків і кораблів ВМС. змоги їх відстежувати 3 використанням 
Спецслужби США змінили орбіту одного зі своїх найефективніших супутників-шпигунів КН-11, який разом зі спеціальними розвідувальними літаками використовувався

для електронного полювання за саудівським мільйонером і терористом № 1 Усамою Бен Ладеном, звинуваченого в організації терактів в США.

Таблиця 3

Космічні апарати розвідки і спостереження (ISAF, Афганістан, 2001)

\begin{tabular}{|c|c|c|c|}
\hline Країна & Найменування КА & Апаратура & Примітка \\
\hline США & КН-11 & ОЕР & військовий \\
\hline США & Lacrosse & РЛР & військовий \\
\hline США & Magnum & PP & військовий \\
\hline США & Ferret & PTP & військовий \\
\hline США & Chalet & PTP & військовий \\
\hline США & Aquacade & PEP & військовий \\
\hline США & OrbView & OEC & цивільний \\
\hline США & Landsat & OEC & цивільний \\
\hline Ізраїль & Eros & OEC & цивільний \\
\hline Франція & Spot & OEC & цивільний \\
\hline Франція & Нelios & OEC & цивільний \\
\hline
\end{tabular}

ISAF - Міжнародні сили сприяння безпеці.

Результати застосування сил і засобів космічної розвідки в Афганістані дають змогу стверджувати, що супутникові системи США змогли забезпечити проведення антитерористичної операції необхідними розвідувальними даними, хоча і відзначалася недостатня періодичність спостереження районів ведення бойових дій.

Друга війна в Іраку (2003) виявилася мультимедійною бойовою акцією, яка коли- небудь проводилася Сполученими Штатами. Бомби, ракети, літаки, танки та інша техніка всі вони були підключені до віддалених командних центрів через військові супутники.

Операція, як і кампанія НАТО проти Югославії, характеризувалася активним застосуванням як військових розвідувальних супутників, так i цивільних супутників дистанційного зондування Землі (Табл. 4) [2, $4,5,8-10]$.

Таблиця 4

Космічні апарати розвідки і спостереження (США та Велика Британія, Ірак, 2003)

\begin{tabular}{|c|c|c|c|}
\hline Країна & Найменування КА & Апаратура & Примітка \\
\hline США & КН-11 & ОЕР & військовий \\
\hline США & Lacrosse & РЛР & військовий \\
\hline США & Magnum & PP & військовий \\
\hline США & Ferret & PTP & військовий \\
\hline США & Chalet & PTP & військовий \\
\hline США & Aquacade & PEP & військовий \\
\hline США & OrbView & OEC & цивільний \\
\hline США & Landsat & OEC & цивільний \\
\hline Ізаїль & Eros & OEC & цивільний \\
\hline Франція & Spot & OEC & цивлльний \\
\hline Франція & Helios & OEC & цивільний \\
\hline
\end{tabular}

Великого значення, до того ж, мали супутники видової розвідки. Космічні апарати оптико-електронної розвідки вели цілодобове спостереження за угрупованнями іракських військ і їх переміщенням, а також здійснювали контроль нанесення ракетно-бомбових ударів по об'єктах на території Іраку з використанням апаратури, що працювала у видимому та інфрачервоному діапазонах. Застосування супутників радіолокаційної розвідки забезпечувало ведення не тільки видової розвідки, але і можливість виявлення ядерної, хімічної та бактеріологічної зброї за допомогою спеціальних приладів, встановлених на борту супутників.
Оцінюючи

результати

операції “Свобода Іраку” можна дійти висновку про активне використання можливостей космічної розвідки на ТВД, яка надавала американобританським коаліційним силам необхідні дані про противника, забезпечуючи тим самим вогневе ураження його сил і засобів, а також оперативне управління військами i зброєю.

Biйна в Сирії (з 2014), до якої з плином часу виявилися залучені не тільки основні держави регіону, а й міжнародні організації, військово-політичні угруповання і світові держави, має свої особливості. Вони обумовлені участю у війні США і Росії 3 протилежними поглядами на ситуацію та 
правлячий режим під керівництвом Башара Асада. Така ситуація між Росією і США склалася вперше після непрямого військового протистояння США і СРСР у локальних війнах $\mathrm{XX}$ ст. в умовах існування двох протилежних світових політичних систем: капіталістичної та соціалістичної.

Військове втручання США та низки інших західних i близькосхідних держав у громадянську війну в Сирії 3 офіційно заявленою метою боротьби проти терористичної організації "Ісламська держава", а також пов'язаного 3 “Аль-Каїдою” угруповання “Фронт ан-Нусра", почалося у вересні 2014 року нанесенням авіаударів по об'єктах на сирійській території в рамках військової операції проти "Ісламської держави".

Збройні сили Росії розпочали свої дії проти терористичних формувань "Ісламської держави" i “Джебхат ан-Нусра" на стороні урядових військ і проурядових воєнізованих формувань у Сирії з вересня 2015 року.

У рамках посилення контролю території Сирії та виявлення наземних цілей для наступного ураження під час військових операцій 3 обох сторін активно застосовувалися засоби космічної розвідки і спостереження (Табл. 5) [11-20].

Таблиця 5

Космічні апарати розвідки і спостереження (РФ і коаліція на чолі з США, Сирія, з 2014)

\begin{tabular}{|c|c|c|c|}
\hline Країна & Найменування КА & Апаратура & Примітка \\
\hline США & KH-11 & OEP & військовий \\
\hline США & Lacrosse & РЛР & військовий \\
\hline США & FIA-Radar & РЛР & військовий \\
\hline США & Ferret & PTP & військовий \\
\hline США & Aquacade & PEP & військовий \\
\hline США & Jumpseat & OEP & військовий \\
\hline США & Quick Bird & OEC & цивільний \\
\hline США & WorldView & OEC & цивільний \\
\hline США & SkySat & $\mathrm{OEC}$ & цивільний \\
\hline Ізраїль & Eros & OEC & цивільний \\
\hline Франція & Spot & OEC & цивільний \\
\hline Франція & Pleiades & OEC & цивільний \\
\hline $\mathrm{P} \Phi$ & Персона & OEP & військовий \\
\hline $\mathrm{P} \Phi$ & Кондор & РЛР & військовий \\
\hline PФ & Лотос & PTP & військовий \\
\hline $\mathrm{P} \Phi$ & Кобальт & ОЕР (фото) & військовий \\
\hline $\mathrm{P} \Phi$ & Барс & OEC & військовий \\
\hline $\mathrm{P} \Phi$ & Pecypc & $\overline{\mathrm{OEC}}$ & цивільний \\
\hline $\mathrm{P} \Phi$ & Канопус & OEC & цивільний \\
\hline
\end{tabular}

За результатами аналізу світового досвіду застосування засобів космічної розвідки під час бойових дій можна дійти таких висновків: інтеграція засобів повітряної та космічної розвідок і засобів ураження противника; спільне використання військових i цивільних засобів космічної розвідки та спостереження; зменшення часу від моменту добування розвідувальних даних засобами космічної розвідки до моменту ïх надання (доведення) зацікавленим командним інстанціям; ведення цілодобового суцільного спостереження за будь-яким районом земної кулі і визначення координат об'єктів спостереження 3 точністю від $0,1 \mathrm{~m}$ до $5 \mathrm{~m} \quad 3$ високою оперативністю.

Подальший розвиток збройної боротьби свідчить, що майбутня збройна боротьба буде характеризуватися перенесенням основних зусиль у повітряно-космічний простір, широким застосуванням космічних розвідувальних, навігаційних і ударних систем, а також систем зв'язку.
Розвідувальні системи здобування інформації та засоби передачі даних в основному розташовуватимуться в повітряно-космічному просторі. Сфера діяльності розвідки охопить програмне забезпечення, комп'ютерні мережі, телекомунікаційні системи, засоби масової інформації та інші сфери. Зростання обсягу розвідувальної інформації про противника потребуватиме застосування нових методів іiі оброблення 3 використанням елементів “штучного інтелекту".

Характерною рисою, що буде притаманна застосуванню космічних систем і засобів, стане створення й активне використання космічних ударних озброєнь, здатних уражати космічні, наземні (морські) i повітряні цілі в масштабі часу, близькому до реального, у глобальному масштабі 3 використанням зброї на нових фізичних принципах.

Висновки. Підводячи підсумок, слід зазначити, що досвід локальних війн i 
воєнних конфліктів свідчить про те, що космічна розвідка $є$ необхідним та надважливим елементом інфраструктури держави, що має сучасні збройні сили, а застосування космічних апаратів розвідки $є$ саме тим критичним фактором, який завчасно забезпечує країнам, що ïx мають, перевагу i перемогу у збройних конфліктах.

\section{Подальші дослідження мають} відбуватися за такими актуальними напрямами: тенденції в інтеграції космічної розвідки 3 іншими видами військової розвідки; способи маскування наземних об'єктів від космічних засобів розвідки противника; способи створення та застосування угруповань космічних апаратів розвідки і спостереження під час підготовки та ведення бойових дій тощо.

\section{СПИСОК ВИКОРИСТАНОЇ ЛІТЕРАТУРИ}

1. Тенденції розвитку форм і способів збройної боротьби в сучасних локальних війнах і збройних конфліктах: кол. монографія / П. П. Ткачук, С. П. Мосов, А. П. Красюк та ін. ; за ред. канд. істор. наук Г. П. Воробйова. Львів : НАСВ, $2015.90 \mathrm{c}$.

2. Мосов С. П. Аэрокосмическая разведка в современных военных конфликтах : монография. Киев : Изд. дом “РУМБ”, 2008. 248 с.

3. Revue Aerospatiale.1995. № 115. Р. 27.

4. Аерокосмічна розвідка в локальних війнах сучасності: досвід, проблемні питання і тенденції: кол. монографія / Л. М. Артюшин, С. П. Мосов, Д. В. П'ясковський, В. Б. Толубко. Київ: НАОУ, 2002. $208 \mathrm{c}$.

5. Меньшаков Ю. К. Техническая разведка из космоса. Москва: Academia, 2013. 656 с.

6. Keaney T. A., Cohen E. A. Revolution in Warfare? Air Power in the Persian Gulf. Annapolis, Maryland, 1993. $316 \mathrm{p}$.

7. Гарбук С., Белокопытов Р. Использование в военных целях космических аппаратов дистанционного зондирования Земли. URL: http://commi.narod.ru/txt/1995/ 0905.htm (дата звернення: 08.04.2019).

8. Копылов А.И., Пивоваров Ю.Ф. Влияние естественных факторов на эффективность применения космических систем США в ходе военных действий в зоне Персидского залива (19902003). Военная Мысль. 2018. № 3 С. 68-78.

9. Романов Н. Военно-космическая разведка США в современных локальных конфликтах. URL: http://artofwar.ru (дата звернення: 08.04.2019).
10. Чупарис А. Использование США космической группировки в войне против Ирака. URL: http://pentagonus.ru/publ/14-1-0-288 (дата звернення: 08.04.2019).

11. New generations of satellites are Russia's cosmic eyes and ears. URL: https://www.rbth.com/defence/ 2015/12/14/new-generations-of-satellites-arerussias-cosmic-eyes -and-ears_550803 (дата звернення: 08.04.2019).

12. Russia's Advanced New Surveillance Satellites to Keep an Eye on US Carriers. URL: http://www.spacedaily.com/reports/Russias_Advan ced_New_Surveillance_Satellites_to_Keep_an_Ey e_on_US_Carriers_999.html (дата звернення: 08.04.2019).

13. Russia reinforces Satellite Support of Military Activities in Syria. URL: http://spaceflight101.com/ russia-reinforcessatellite-support-of-military-activities-in-syria/ (дата звернення: 08.04.2019).

14. Russia Using Space Warfare Systems in Syrian War. URL: https://freebeacon.com/ nationalsecurity/russia-space-warfare-systems-syrian-war/ (дата звернення: 08.04.2019).

15. Satellite Imagery Analysis for Urban Conflict Documentation: Aleppo, Syria. URL: https://www.aaas.org/resources/satellite-imageryanalysis-urban-conflict-documentation-aleppo-syria (дата звернення: 08.04.2019).

16. Фишман А. Израиль видит все: на что способны израильские спутники. URL: http://www.proatom.ru/modules.php?name=News

\&file=article\&sid=3299 (дата звернення: 08.04.2019).

17. Итоги запусков спутников съемки Земли в 2012 году: наступление Китая и возрождение Франции. URL: http://club.cnews.ru/blogs/ entry/itogi_zapuskov_sputnikov_

semki_zemli_v_2012_godu_nastuplenie_kitaya_i_ vozrozhdenie_frantsii (дата звернення: 08.04.2019).

18. Итоги запусков спутников съемки Земли в 2014 году: рекордный рост и наступление наноспутников. URL: http://dauria.ru/img/uplfile/ itogi-dzz-20141.pdf.

19. Кучейко А. А. Мировая отрасль космической съемки в итогах запусков спутников. Земля из космоса. 2016. № 6 (22). С. 55-65.

20. Кучейко А. А. Мировая отрасль космической съемки. Итоги запусков КА ДЗ3 в 2016 г. и І квартале 2017 г.* Геопрофи. 2017. № 3. С. 4-8. 
Мосов С. П., д-р воен. наук, профессор ${ }^{1}$;

Селюков А. В., д-р техн. наук, ст. науч. сотр. ${ }^{2}$

1 - Национальный центр управления и испытаний космических средств, Киев;

2 - Киевский национальный университет строительства и архитектуры, Киев

\section{Космическая разведка в локальных войнах и вооруженных конфликтах современности}

Резюме. На основе анализа мирового опыта исследовано применение разведывательных спутников и спутников двойного назначения в системе обеспечения боевых действий на примерах известных локальных войн и вооруженных конфликтов конца XX - начала XXI веков: Ирак, 1991 год; Югославия, 1999 год; Афганистан, 2001 год; Ирак, 2003 год; Сирия, с 2014 года. Акцентировано внимание на особенностях применения космических аппаратов разведки, присущих каждой из локальных войн с учетом соответствующего театра военных действий, возможностей космической разведки государств, принимавших в них участие. Приведена информация об орбитальных группировках космических аппаратов, выполнявших задачи разведки в интересах наземных войск в различных диапазонах длин волн электромагнитного спектра. Сделаны выводы о тенденциях космической разведки, а также определены перспективы развития космического сегмента в системе обеспечения будущих боевых действий.

Ключевые слова: космическая разведка; вооруженная борьба; локальная война; театр военных действий; космический аппарат.

\section{S. Mosov, DsM, professor ${ }^{1}$}

O. Sieliukov, DsT, senior researcher ${ }^{2}$

1 - National Space Facilities Control and Test Center, Kyiv;

2 - Kyiv National University of Civil Engineering and Architecture, Kyiv

Space intelligence in local wars and armed conflicts of modern times

Resume. On the basis of the analysis of world experience, the use of reconnaissance satellites in the system of providing combat actions on the examples of known local wars and armed conflicts of the late XX - early XXI centuries has been investigated: Iraq, 1991; Yugoslavia, 1999; Afghanistan, 2001; Iraq, 2003; Syria since 2014. The attention was paid to the peculiarities of the use of space reconnaissance craft, which were inherent in each of the local wars, taking into account the relevant arena of war, space reconnaissance capabilities of the states that took part in them. Information is given about orbital groups of spacecrafts that performed reconnaissance tasks in the interests of ground troops in different ranges of wavelengths of the electromagnetic spectrum. Conclusions regarding space reconnaissance trends are made, as well as the prospects for the development of the space segment in the system of providing future military struggle.

Keywords: space reconnaissance; military struggle; local warfare; arena of war; spacecraft. 